\title{
Nitrogen secretion and absorption in different segments of the digestive tract estimated by digesta exchange between ${ }^{15} \mathrm{~N}$-labelled and unlabelled sheep* $^{*}$
}

\section{K. Krawielitzki', Antje Sandek ${ }^{2}, J_{\text {. Kowalczyk }}^{3}$, F. Kreienbring', Teresa Żebrowska ${ }^{3}$, Beata Skiba ${ }^{3}$, J. Voigt ${ }^{4}$, M. Gabel ${ }^{2}$ and H. Hagemeister ${ }^{4}$}

\author{
'Institute for Applied Agroecology, Justus-von-Liebig-Weg 8. 18059 Rostock, Germany \\ 'University of Rostock, Institute for Compatible Animal Husbandry \\ Justus-von-Liebig-Weg 818059 Rostock, Germany \\ ${ }^{3}$ Kielanowski Institute of Animal Physiology and Nutrition, Polish Academy of Sciences \\ 05 - 110 Jablonna near Warsaw, Poland \\ ${ }^{4}$ Research Institute for the Biology of Farm Animals, Department of Nutritional Physiology \\ "Oskar Kellner", 18059 Rostock, Germany
}

(Received 7 January 1999; accepted 19 March 1999)

\begin{abstract}
Three malc shecp of about $25 \mathrm{~kg}$ body weight fitted with a cannula into the rumen and reentrant cannula in the proximal duodenum and in the distal ileum were used for this study. Sheep No. 1 was infused intraruminally with ${ }^{15} \mathrm{~N}$ urea $\left(1 \mathrm{~g} / \mathrm{d}, 95\right.$ atom $\left.\%{ }^{15} \mathrm{~N}\right)$ for labelling with ${ }^{15} \mathrm{~N}, \mathrm{Nos} .2$ and 3 with unlabelled urea. All animals were fed $800 \mathrm{~g} \mathrm{DM} / \mathrm{d}$ of a hay and concentrate diet $(40: 60)$ containing $15.4 \%$ crude protein and $15.3 \%$ crude fibre, divided into 6 feeding portions per day. After reaching a quasi-steady state in the ${ }^{15} \mathrm{~N}$ level of animal No. 1, passage of total $\mathrm{N}$ and ${ }^{15} \mathrm{~N}$ throughout the duodenum and the ileum, $\mathrm{N}$ excretion in faeces and urine were estimated. On day 7 and 8 of the experiment the duodenal and ileal digesta were exchanged between the labelled animal (No. 1) and the unlabelled ones (No. 2,3) according to the respective scheme. Digesta flow was measured directly during $48 \mathrm{~h}$ and $3 \%$ aliquots were sampled for analysis of $\mathrm{N}$ and ${ }^{15} \mathrm{~N}$ content. The contents of $\mathrm{N}$ and
\end{abstract}

\footnotetext{
- Supported by the State Committee for the Scientific Research, Grant No 5 POGE 03312 and by the Deutsche Forschungsgemeinschaft (DFG)
} 
${ }^{15} \mathrm{~N}$ were also estimated in faeces, urine and blood. The obtained data were used for calculation of the passage and absorption of exogenous $\mathrm{N}$ and the secretion, absorption and reabsorption of endogenous $\mathrm{N}$ in three digestive sections from mouth to proximal duodenum, from duodenum to ileum, and from ileum to rectum.

The flow of total $\mathrm{N}$, exogenous $\mathrm{N}$ and endogenous $\mathrm{N}$ decreased from duodenum to ileum and faeces, but the relative content of endogenous $\mathrm{N}$ increased from 36 to $54 \%$. N-secretion was highest in the first section of the digestive tract $(9.9 \mathrm{~g} \mathrm{~N} / \mathrm{d}=60 \%$ of the secretion in total digestive tract $)$ and absorption was highest in the second section $(14.1 \mathrm{~g} \mathrm{~N} / \mathrm{d}=46 \%$ of total absorption). Endogenous origin $\mathrm{N}$ was about $54 \%$ of faecal $\mathrm{N}$. Faecal loss, $2.0 \mathrm{~g}$ endogenous $\mathrm{N} / \mathrm{d}$, was only about $12 \%$ of the total endogenous $\mathrm{N}(16.5 \mathrm{~g} \mathrm{~N})$ secreted into the lumen during the intestinal passage of digesta. Total reabsorption of endogenous $\mathrm{N}$ amounted to $88 \%$. The results demonstrate the high dynamics of $\mathrm{N}$ metabolism during digestion in ruminants.

KEY WORDS: sheep, passage rate, ${ }^{15} \mathrm{~N}$, endogenous $\mathrm{N}$, exogenous $\mathrm{N}$, absorption, secretion, reabsorption

\section{INTRODUCTION}

Absorption of nitrogen compounds along the digestive tract of animals is accompanied by secretion of endogenous nitrogen into the intestinal lumen and both of these processes occur simultaneously. It is difficult to quantify them because of the lack of accurate methods for differentiation between endogenous and exogenous compounds of the digesta (Krawielitzki et al., 1990, 1996). In ruminants the situation is even more complicated because of their ability to utilise NPN compounds for protein synthesis and to recycle $\mathrm{N}$ into the rumen (Kowalczyk et al., 1975; Ivan et al., 1981; Żebrowska and Kowalczyk, 1991; Van Bruchem et al., 1997). Nitrogen digestibility in the gastro-intestinal tract and $\mathrm{N}$ recycling are influenced by different factors. Better understanding of the processes of $\mathrm{N}$ absorption, secretion and recycling in different sections of the digestive tract is required to increase $\mathrm{N}$ utilization and to reduce $\mathrm{N}$ excretion by ruminants.

Therefore, the main objectives of the present study with growing sheep were to determine:

- the proportion of endogenous $\mathrm{N}$ :exogenous $\mathrm{N}$ in different sections of the ruminant digestive tract,

- to estimate the amount of endogenous $\mathrm{N}$ secreted and absorbed in different sections of the digestive tract,

- to evaluate the reabsorption of endogenous $\mathrm{N}$ along the intestine.

These processes were investigated by means of digesta exchange between ${ }^{15} \mathrm{~N}$-labelled and unlabelled animals. 


\section{MATERIAL AND METHODS}

\section{Animals}

Three 5-month-old Polish Merino male sheep of about $25 \mathrm{~kg}$ body weight were fitted with a cannula in the rumen and re-entrant cannulas at the duodenum distal to the pancreatic duct opening and at the ileum about $25 \mathrm{~cm}$ before the ileo-caecal junction. Animal No. 1 was also equipped with a catheter into the jugular vein for blood sampling.

\section{Feeding}

The animals were given $800 \mathrm{~g}$ dry matter of a cut meadow hay and concentrate diet (40:60) daily. The pelleted concentrate was composed of ground barley $82.2 \%$, soyabean meal $15.8 \%$ and vitamin-mineral mixture $2.0 \%$. The diet contained in $1 \mathrm{~kg}$ of dry matter: $154 \mathrm{~g}$ crude protein, $153 \mathrm{~g}$ crude fibre, $63.5 \mathrm{~g}$ ash, $16.7 \mathrm{~g}$ ether extract and 11.0 MJ ME. Rations were fed in 6 equal portions in $4 \mathrm{~h}$ intervals. Water was available ad libitum. Feed refusals were collected and weighed daily.

\section{Housing}

During the recovery period the animals were housed individually in pens on sawdust bedding. During the experiment they were kept in metabolic cages permitting quantitative collection of faeces and urine and sampling of ruminal, duodenal and ileal digesta.

\section{Experimental design and sampling}

The experiment was divided into 3 periods: labelling (day 1-6); digesta exchange (day 7-8) and clearance (day 9-10). Four weeks after surgery during the labelling and exchange periods animal No. 1 was continuously infused intraruminally with $1 \mathrm{~g} / \mathrm{d}$ uniformly labelled ${ }^{15} \mathrm{~N}$ urea $\left(95 \%{ }^{15} \mathrm{~N}\right.$ atom excess). Animals No. 2 and 3 were simultaneously infused intraruminally with the same amount of unlabelled urea.

During the two days of the exchange period the duodenal and ileal digesta were collected continuously, measured and $3 \%$ aliquots from $4 \mathrm{~h}$ intervals were pooled for $24 \mathrm{~h}$ samples and then frozen at $-20^{\circ} \mathrm{C}$ until analysis for nitrogen and ${ }^{15} \mathrm{~N}$ content. Digesta was kept during collection at $0^{\circ} \mathrm{C}$ and after sampling warmed to $38^{\circ} \mathrm{C}$ and exchanged between animals according to the scheme given in Figure 1.

Faeces and urine were collected during all 3 experimental periods. Collected faeces was preserved with a few drops of chloroform, measured and sampled 
Animal No. 3

(unlabelled)
Animal No. 1

$\left({ }^{15} \mathrm{~N}\right.$ labelled)
Animal No. 2

(unlabelled)

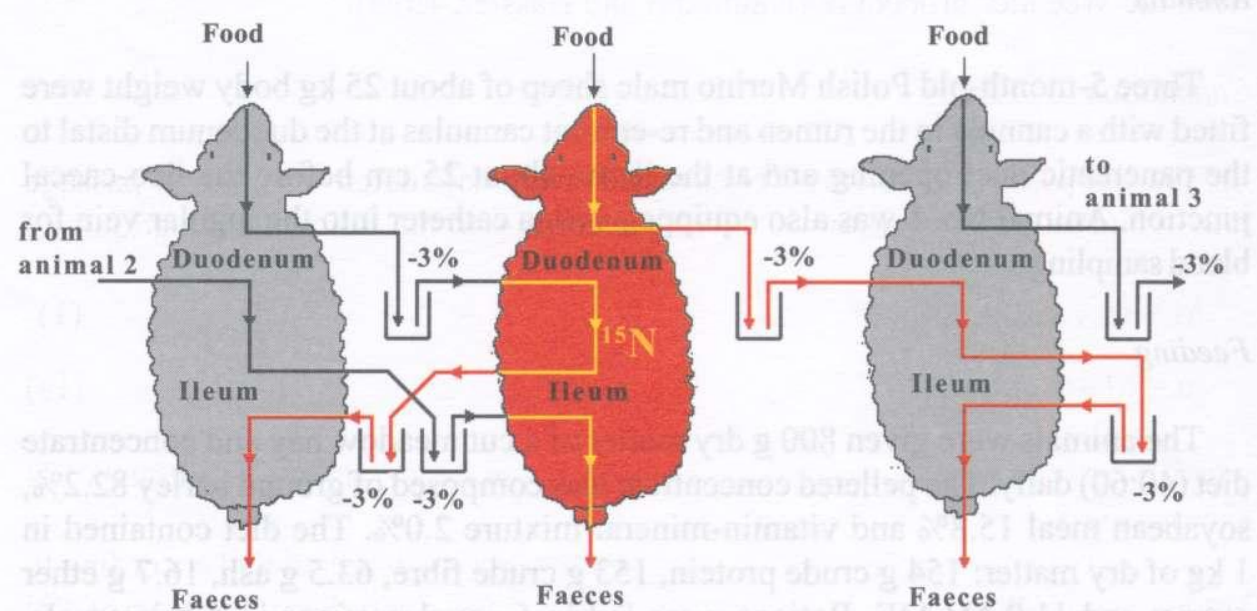

Figure 1. Scheme of digesta exchange between labelled and unlabelled sheep

every $24 \mathrm{~h}$. Urine was collected using the device described by Kowalczyk et al. (1996) into vessels with $100 \mathrm{ml} 6 \mathrm{~N}$ sulphuric acid in intervals of $24 \mathrm{~h}$ except on day 1 (start of labelling period) and day 9 (first day of clearance period) where intervals of $4 \mathrm{~h}$ were chosen.

The obtained data were used to calculate passage and absorption of exogenous $\mathrm{N}$ and secretion, absorption and reabsorption of endogenous $\mathrm{N}$ for three sections of the digestive tract: mouth-duodenum, duodenum-ileum, and ileum-rectum.

Samples of about $50 \mathrm{ml}$ rumen fluid and $5 \mathrm{ml}$ blood from the jugular vein were taken before the morning feeding at 8.00 during all three experimental periods. Bacterial mass from the rumen samples was separated by fractional centrifugation according to Beever et al. (1974). After filtration feed particles were separated by centrifugation at $2800 \mathrm{xg}$ for $10 \mathrm{~min}$ at $5^{\circ} \mathrm{C}$ and then bacteria from the supernatant by centrifugation at $20.000 \mathrm{x}$ g for $30 \mathrm{~min}$ at $2^{\circ} \mathrm{C}$. The bacterial mass was freezedried and analyzed for $\mathrm{N}$ and ${ }^{15} \mathrm{~N}$ content. ${ }^{15} \mathrm{~N} \%$ atom excess was determined in blood plasma obtained by spinning blood samples for $20 \mathrm{~min}$ at $5000 \mathrm{rpm}$.

During the clearance period the decay of ${ }^{15} \mathrm{~N}$ in blood and urine was observed for animal No. 1 after ending the infusion of ${ }^{15} \mathrm{~N}$-urea. From these data the half-life of the metabolic pool and the average dwelling time for $\mathrm{N}$ in the body of the animals were estimated.

All samples were stored at $-20^{\circ} \mathrm{C}$ until analysis for $\mathrm{N}$ by the Kjeldahl method and for ${ }^{15} \mathrm{~N}$ after chemical preparation according to Voigt et al.(1980) by means of 
isotope mass spectrometry (Delta S, Finnigan MAT, Bremen, Germany). In the experimental diet DM, ash, crude fibre and ether extract were determined following the Weender procedure (Naumann and Bassler, 1993).

\section{Calculation}

The ${ }^{15} \mathrm{~N}$ passage rates $\left(\mathrm{mg}{ }^{15} \mathrm{~N}\right.$ excess $/ \mathrm{d}$ ) were calculated from the $\mathrm{N}$ passage rate $(\mathrm{g} \mathrm{N} / \mathrm{d})$ and the ${ }^{15} \mathrm{~N}$ [atom\% excess] according to the following equations:

$$
\begin{aligned}
& \mathrm{M}=\mathrm{m} \times \mathrm{a} / 100 \times 15 / 14 \\
& \mathrm{~m}=\mathrm{M} \times 100 / \mathrm{a} \times 14 / 15
\end{aligned}
$$

where $\mathrm{M}=m g{ }^{15} \mathrm{~N}$ excess; $\mathrm{m}=\mathrm{mg} \mathrm{N}$ (here $\mathrm{mg}$ endogenous $\mathrm{N}$ ); $a=a$ atom $\%{ }^{15} \mathrm{~N}$ excess (see Schubert, 1995).

The amount of endogenous $\mathrm{N}$ in digesta and faeces was calculated according to Voigt et al. (1996) and to Van Bruchem et al. (1997) from the proportion of ${ }^{15} \mathrm{~N}$ [atom\% excess] of this fraction and ${ }^{15} \mathrm{~N}$ excess of the blood plasma NPN fraction and the $\mathrm{N}$ content of the fraction using the equation:

$$
\text { endogenous } \mathrm{N}[\mathrm{g} / \mathrm{d}]=\mathrm{N}[\mathrm{g} / \mathrm{d}] \times \frac{{ }^{15} \mathrm{~N} \text { excess in digesta resp. faeces }}{{ }^{15} \mathrm{~N} \text { excess in plasma NPN }}
$$

The exogenous $\mathrm{N}$ in digesta $\mathrm{N}$ and faecal $\mathrm{N}$ were calculated as the difference of total and endogenous $\mathrm{N}$ :

$$
\text { exogenous } \mathrm{N}[\mathrm{g} / \mathrm{d}]=\text { total } \mathrm{N}[\mathrm{g} / \mathrm{d}] \text { - endogenous } \mathrm{N}[\mathrm{g} / \mathrm{d}]
$$

The data of total $\mathrm{N}$, endogenous $\mathrm{N}$ and exogenous $\mathrm{N}$ of duodenal digesta, ileal digesta, and faeces and the appearance, and disappearance rates of $\mathrm{N}$ and ${ }^{15} \mathrm{~N}$ during passage through the different intestinal sections were the basis for further computing $\mathrm{N}$ secretion and $\mathrm{N}$ absorption in the 3 digestive segments: mouth-duodenum, duodenum-ileum, and ileum-anus.

\section{RESULTS}

All sheep were in good condition during the whole experiment. Feed intake was diminished from $19.1 \mathrm{~g} \mathrm{~N} / \mathrm{d}$ during the labelling period to $17.6 \mathrm{~g} \mathrm{~N} / \mathrm{d}$ during the exchange period (both including $0.45 \mathrm{~g} \mathrm{~N} / \mathrm{d}$ from urea infusion). 


\section{Nbalance}

The nitrogen balance of the three experimental animals estimated during the 6-day labelling period is shown in Table 1, which demonstrates an average balance of $6.9 \mathrm{~g} \mathrm{~N} / \mathrm{d}$ corresponding to protein accretion of $43 \mathrm{~g} / \mathrm{d}$ that is the normal value for sheep under such conditions. On average $41.4 \%$ of $\mathrm{N}$ intake was excreted in urine and $22.2 \%$ in faeces. The corresponding data for ${ }^{15} \mathrm{~N}$ were $50.2 \%$ of the ${ }^{15} \mathrm{~N}$ infusion dose in urine and $6 \%$ by faeces.

TABLE 1

Nitrogen balance during the 6 day labelling period

\begin{tabular}{lccccc}
\hline Animal & No. 1 & No. 2 & No. 3 & x & \pm SD \\
\hline N intake (total), g/d & 19.44 & 17.32 & 20.47 & 19.08 & 1.61 \\
Food N, g/d & 18.99 & 16.85 & 20.00 & 18.61 & 1.61 \\
N infusion, g/d & 0.45 & 0.47 & 0.47 & 0.47 & 0.01 \\
N excretion & & & & & \\
$\quad$ urine N, g/d & 8.31 & 5.97 & 9.41 & 7.90 & 1.76 \\
$\quad$ faeces N, g/d & 4.27 & 4.46 & 4.00 & 4.24 & 0.24 \\
N accretion, g/d & 6.86 & 6.89 & 7.06 & 6.94 & 0.11 \\
$\quad$ \% of intake & 35.3 & 39.8 & 34.5 & 36.5 & 2.86 \\
Apparent digestibility, \% & 78.0 & 74.2 & 80.5 & 77.6 & 3.13 \\
\hline
\end{tabular}

Course of ${ }^{15} \mathrm{~N}$ level

One of the main conditions for the estimation of endogenous $\mathrm{N}$ in different sections of the intestine was the steady-state of labelling animal No. 1 and reaching a steady-state in ${ }^{15} \mathrm{~N}$ level before starting the exchange period, which was the main period of the experiment.

Figure 2 demonstrates the course of ${ }^{15} \mathrm{~N}$ level in microbial protein isolated from the rumen and Figure 3 the course of ${ }^{15} \mathrm{~N}$ level in the TCA-soluble fraction of blood plasma of animal No 1. Both figures show an exponential increase of ${ }^{15} \mathrm{~N}$ reaching a plateau within the labelling period of 6 days. Figure 3 demonstrates additionally:

- a small decrease of the ${ }^{15} \mathrm{~N}$ plateau during the exchange period (day 7-8) caused by the exchange of labelled digesta in the duodenum of animal No. 1 against unlabelled digesta of animal No. 3 during this period,

- exponential decay of ${ }^{15} \mathrm{~N}$ content during the clearance period (day 9-10),

- that the exponential decrease during the clearance period was nearly the same as the exponential increase during the labelling period.

An analogous course was shown for ${ }^{15} \mathrm{~N}$ excess in urine (Figure 4). 


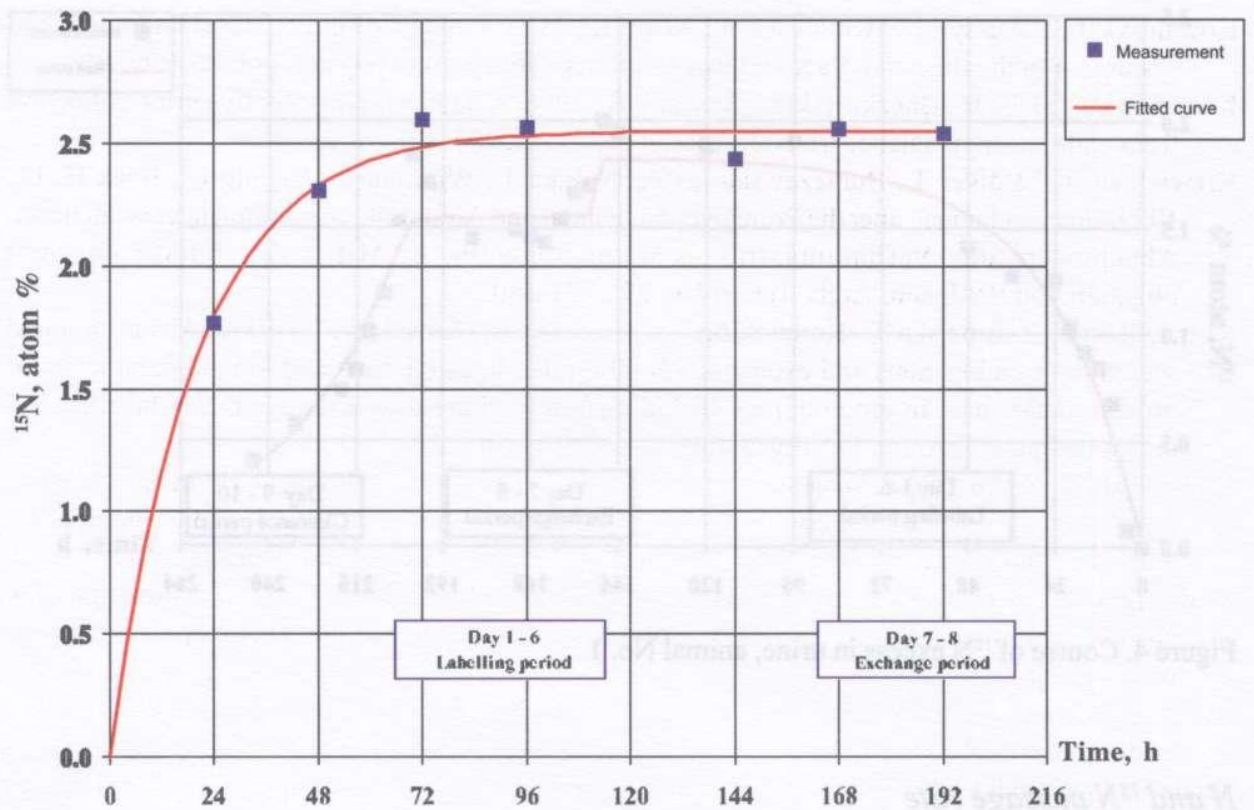

Figure 2. Course of ${ }^{15} \mathrm{~N}$ excess in microbial protein in the rumen, animal No. 1

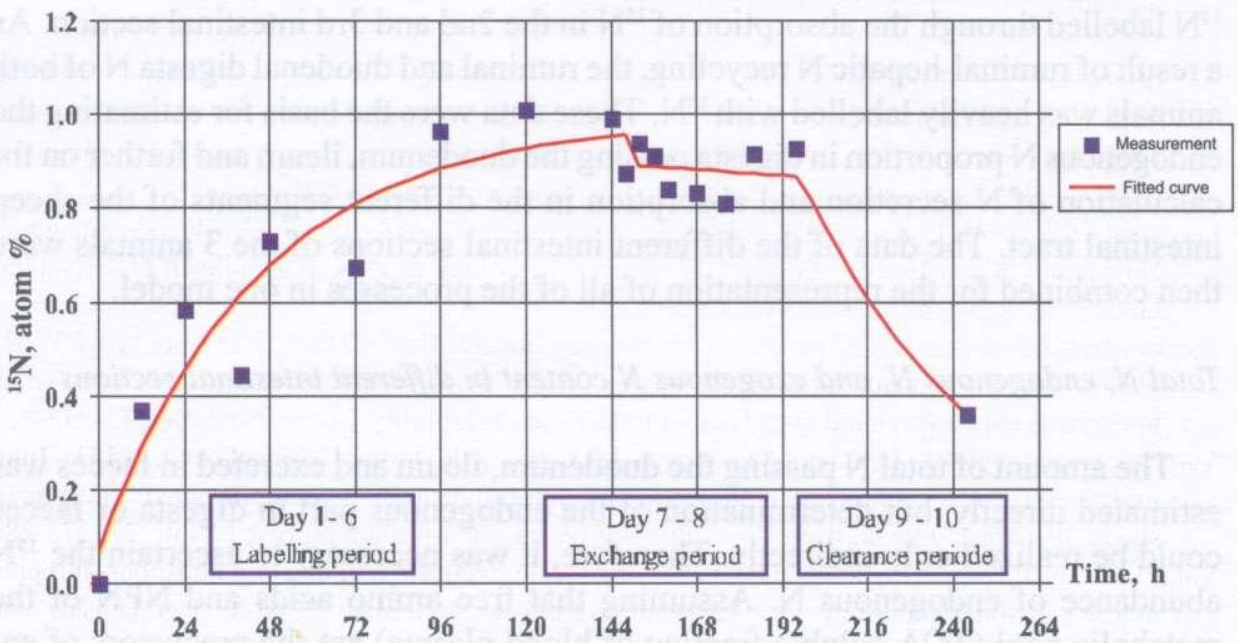

Figure 3. Course of ${ }^{15} \mathrm{~N}$ excess (atom\%) in blood plasma (TCA soluble fraction), animal No. 1 


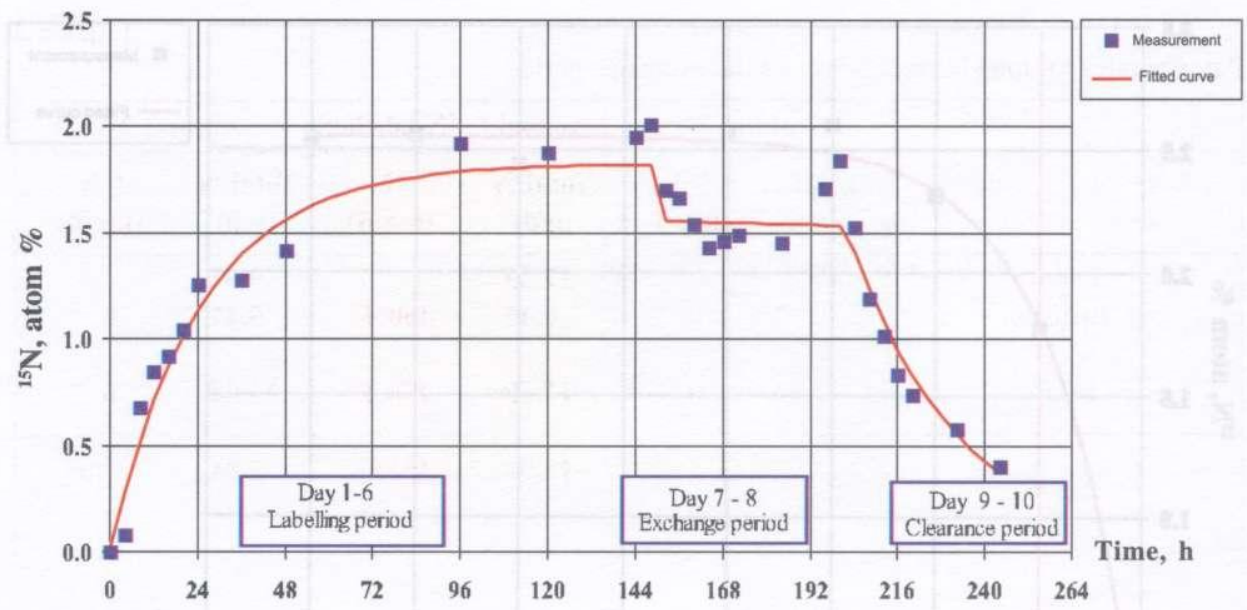

Figure 4. Course of ${ }^{15} \mathrm{~N}$ excess in urine, animal No. 1

\section{$N$ and ${ }^{15} N$ passage rate}

The values for $\mathrm{N}$ and ${ }^{15} \mathrm{~N}$ passage were estimated during the $48 \mathrm{~h}$ exchange period for all three animals; the values beginning with feed intake, duodenal passage, ileal passage, and excreted faeces are given in Table 2. For animal No. 2 the $\mathrm{N}$ intake during the exchange period was considerably smaller than in the labelling period, which was taken into account in the calculations.

During the exchange period the unlabelled animals No. 2 and No. 3 also became ${ }^{15} \mathrm{~N}$ labelled through the absorption of ${ }^{15} \mathrm{~N}$ in the $2 \mathrm{nd}$ and $3 \mathrm{rd}$ intestinal section. As a result of ruminal-hepatic $\mathrm{N}$ recycling, the ruminal and duodenal digesta $\mathrm{N}$ of both animals was heavily labelled with ${ }^{15} \mathrm{~N}$. These data were the basis for estimating the endogenous $\mathrm{N}$ proportion in digesta passing the duodenum, ileum and further on for calculation of $\mathrm{N}$ secretion and absorption in the different segments of the sheep intestinal tract. The data of the different intestinal sections of the 3 animals were then combined for the representation of all of the processes in one model.

\section{Total $N$, endogenous $N$, and exogenous $N$ content in different intestinal sections}

The amount of total $\mathrm{N}$ passing the duodenum, ileum and excreted in faeces was estimated directly, but determination of the endogenous part in digesta or faeces could be realized only indirectly. Therefore, it was necessary to ascertain the ${ }^{15} \mathrm{~N}$ abundance of endogenous N. Assuming that free amino acids and NPN of the metabolic pool (TCA-soluble fraction of blood plasma) are the precursors of endogenous $\mathrm{N}$ compounds secreted into the digestive tract, the ${ }^{15} \mathrm{~N}$ level of this frac- 
TABLE 2

Passage rates for total $\mathrm{N}$ and ${ }^{15} \mathrm{~N}$ excess the exchange period

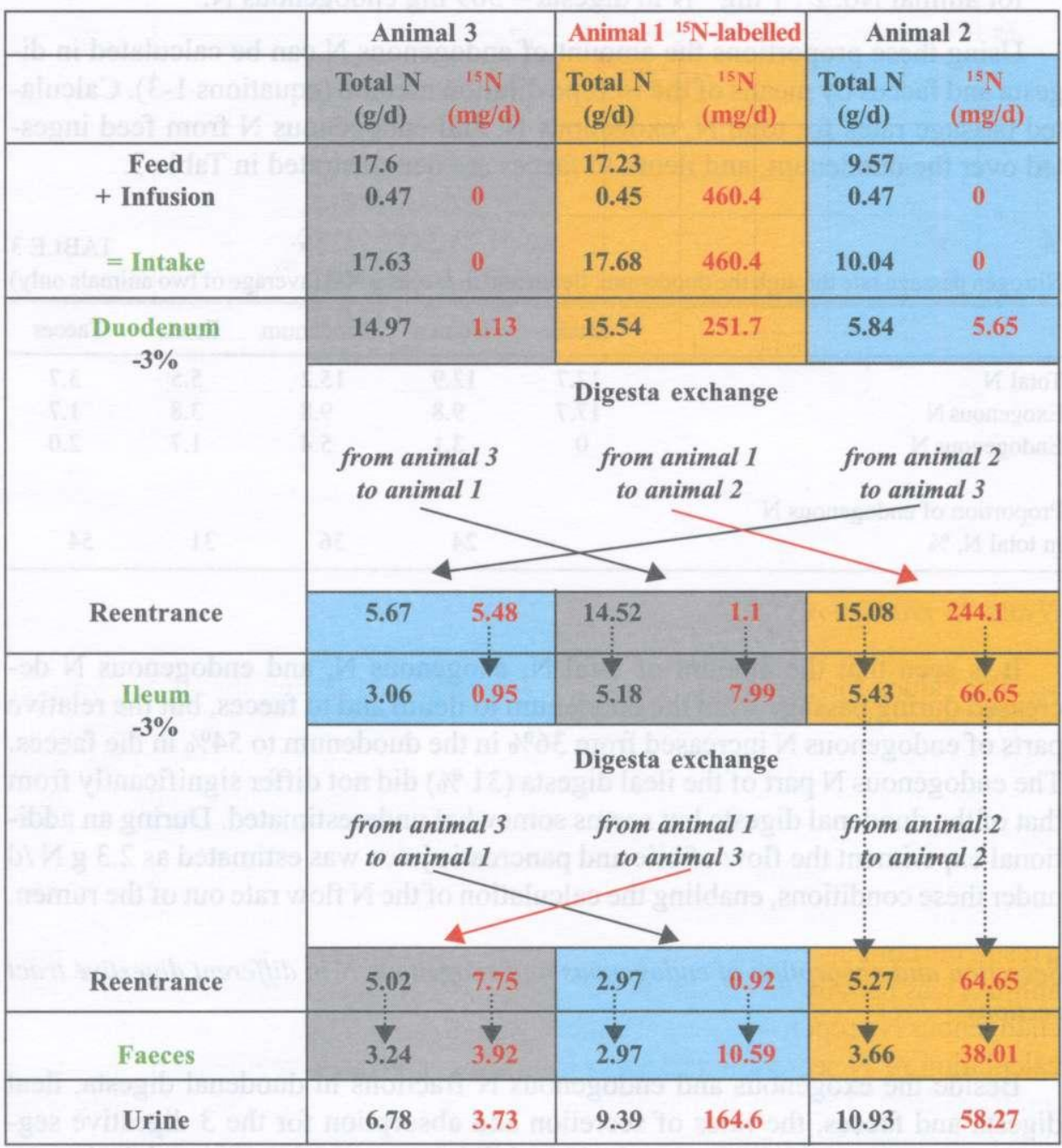

metabolic pool (TCA-soluble fraction of blood plasma) are the precursors of endogenous $\mathrm{N}$ compounds secreted into the digestive tract, the ${ }^{15} \mathrm{~N}$ level of this fraction can be considered to be a suitable indicator for ${ }^{15} \mathrm{~N}$ labelling of endogenous $\mathrm{N}$ (Krawielitzki et al., 1979; Hernandez et al., 1981; Pahle et al, 1981; Bergner and Bergner, 1982). The ${ }^{15} \mathrm{~N}$ level of TCA soluble plasma $\mathrm{N}$ was estimated for animal No. 1 as 0.873 atom\% excess and for animal No. 2 as 0.253 atom \% excess. Assuming this as indicator for endogenous $\mathrm{N}$ and using equation 1 follows: 
for animal No. $1: 1 \mathrm{mg}{ }^{15} \mathrm{~N}$ in digesta $=107 \mathrm{mg}$ endogenous $\mathrm{N}$

for animal No. $2: 1 \mathrm{mg}{ }^{15} \mathrm{~N}$ in digesta $=369 \mathrm{mg}$ endogenous $\mathrm{N}$.

Using these proportions the amount of endogenous $\mathrm{N}$ can be calculated in digesta and faeces by means of the isotope dilution method (equations 1-3). Calculated passage rates for total $\mathrm{N}$, exogenous $\mathrm{N}$, and endogenous $\mathrm{N}$ from feed ingested over the duodenum, and ileum to faeces are demonstrated in Table 3.

TABLE 3

Nitrogen passage rate through the duodenum, ileum and in faeces $\mathrm{g} \mathrm{N} / \mathrm{d}$ (average of two animals only)

\begin{tabular}{lccccc}
\hline & Intake & Rumen & Duodenum & Ileum & Faeces \\
\hline Total N & 17.7 & 12.9 & 15.2 & 5.5 & 3.7 \\
Exogenous N & 17.7 & 9.8 & 9.8 & 3.8 & 1.7 \\
Endogenous N & 0 & 3.1 & 5.4 & 1.7 & 2.0 \\
Proportion of endogenous N & & & & & \\
in total N, \% & & 24 & 36 & 31 & 54 \\
\hline
\end{tabular}

It is seen that the amount of total $\mathrm{N}$, exogenous $\mathrm{N}$, and endogenous $\mathrm{N}$ decreased during passage from the duodenum to ileum and to faeces, but the relative parts of endogenous $\mathrm{N}$ increased from $36 \%$ in the duodenum to $54 \%$ in the faeces. The endogenous $\mathrm{N}$ part of the ileal digesta (31\%) did not differ significantly from that of the duodenal digesta but seems somewhat underestimated. During an additional experiment the flow of bile and pancreatic juice was estimated as $2.3 \mathrm{~g} \mathrm{~N} / \mathrm{d}$ under these conditions, enabling the calculation of the $\mathrm{N}$ flow rate out of the rumen.

Secretion and absorption of endogenous and exogenous $N$ in different digestive tract sections

Beside the exogenous and endogenous $\mathrm{N}$ fractions in duodenal digesta, ileal digesta and faeces, the rates of secretion and absorption for the 3 digestive segments were also estimated using the $\mathrm{N}$ and ${ }^{15} \mathrm{~N}$ passage rates measured during the exchange period of the experiment. Absorption of exogenous $\mathrm{N}$ was estimated as the difference of total $\mathrm{N}$ and endogenous $\mathrm{N}$ for all 3 segments. The secretion and absorption rates for the different segments of the intestinal tract are summarized in the diagram (Figure 5).

The values given in Figure 5 show that:

- secretion was highest in section $1(9.9 \mathrm{~g} \mathrm{~N} / \mathrm{d}$ up to the duodenum including the bile and pancreatic juice),

- secretion into the small intestine behind the pancreatic duct was $4.4 \mathrm{~g} \mathrm{~N} / \mathrm{d}$, 


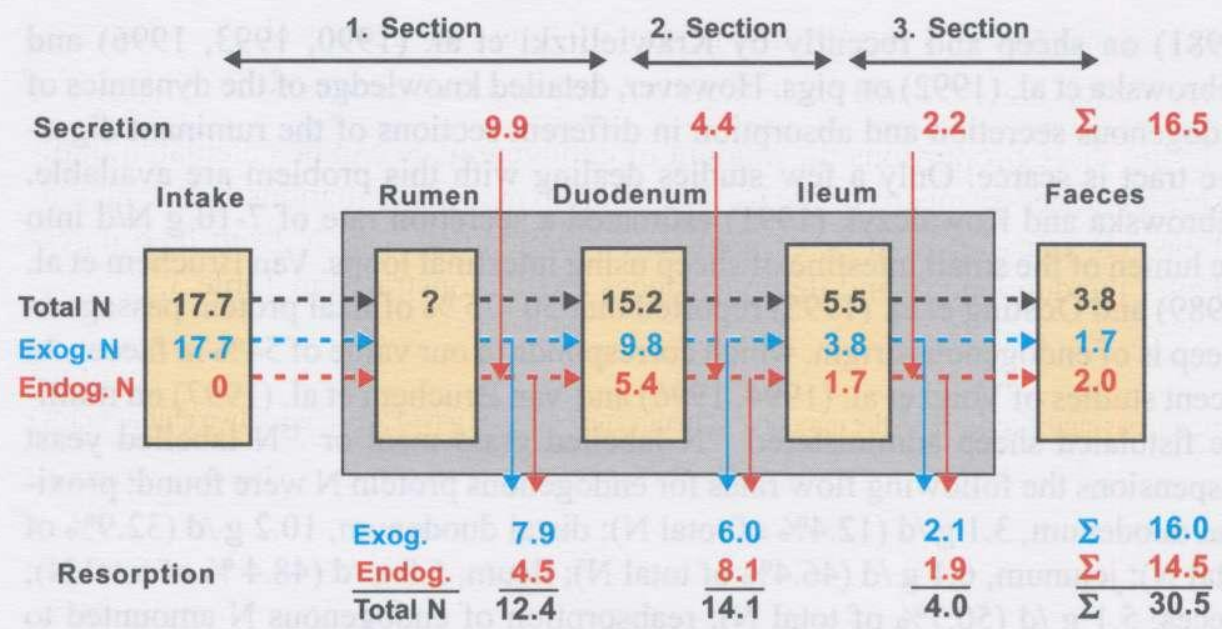

Figure 5. Secretion and absorption rates in the 3 segments of the intestinal tract, $g$ N/d

- total $\mathrm{N}$ secretion was $16.5 \mathrm{~g} \mathrm{~N} / \mathrm{d}$, nearly the amount of $\mathrm{N}$ ingested,

- absorption was highest in section 2 (duodenum - ileum) reaching a value $14.1 \mathrm{~g}$ $\mathrm{N} / \mathrm{d}$, which is about half of the $\mathrm{N}$ absorbed in the whole digestive tract,

- relatively high absorption occurred in section 3 (large intestine),

- total absorption of $\mathrm{N}$ amounted to $30.5 \mathrm{~g} / \mathrm{d}$, which was about $175 \%$ of $\mathrm{N}$ ingested,

- the apparent ileal $\mathrm{N}$ digestibility was $68.9 \%$ and faecal $78.5 \%$, whereas the true ileal $\mathrm{N}$ digestibility was $78.5 \%$ and faecal $90.4 \%$,

- reabsorption of endogenous N was high and amounted to $88 \%$. Only $2.0 \mathrm{~g} / \mathrm{d}=12 \%$ of the endogenous $\mathrm{N}$ secreted into the gut was lost in faeces.

\section{DISCUSSION}

It is difficult to measure the amount of endogenous nitrogen in different segments of the digestive tract because one can not distinguish accurately between nitrogen of endogenous and exogenous origin in the digesta (Low and Żebrowska, 1989). From the different methods reviewed by Souffrant (1991) the ${ }^{15} \mathrm{~N}$ isotope dilution technique seems to be most suitable for this purpose. The application of this method developed for estimation of endogenous secretion in monogastric animals (Bergner et al., 1984; de Lange et al., 1990; Krawielitzki et al., 1990; Żebrowska et al., 1992; Huisman et al., 1992, 1993) is more complicated for ruminants because of rumen digestion and the ruminal-hepatic recycling (Kowalczyk et al., 1975).

The method of digesta exchange between fistulated ${ }^{15} \mathrm{~N}$ labelled and unlabelled animals for investigation of endogenous secretion had been used by Ivan et al. 
(1981) on sheep and recently by Krawielitzki et al. (1990, 1993, 1996) and Żebrowska et al. (1992) on pigs. However, detailed knowledge of the dynamics of endogenous secretion and absorption in different sections of the ruminant digestive tract is scarce. Only a few studies dealing with this problem are available. Żebrowska and Kowalczyk (1991) estimated a secretion rate of 7-10 g N/d into the lumen of the small intestine of sheep using intestinal loops. Van Bruchem et al. (1989) and Oosting et al. (1995) reported that $50-75 \%$ of ileal protein passage in sheep is of endogenous origin, which corresponds to our value of $54 \%$ in faeces. In recent studies of Voigt et al. (1994, 1996) and Van Bruchem et al. (1997) on multiple fistulated sheep administered ${ }^{15} \mathrm{~N}$ labelled grass meal or ${ }^{15} \mathrm{~N}$ labelled yeast suspensions the following flow rates for endogenous protein $\mathrm{N}$ were found: proximal duodenum, $3.1 \mathrm{~g} / \mathrm{d}(12.4 \%$ of total $\mathrm{N})$; distal duodenum, $10.2 \mathrm{~g} / \mathrm{d}(32.9 \%$ of total $\mathrm{N})$; jejunum, $6.1 \mathrm{~g} / \mathrm{d}(46.4 \%$ of total $\mathrm{N})$; ileum, $5.0 \mathrm{~g} / \mathrm{d}(48.4 \%$ of total $\mathrm{N})$; faeces, $5.1 \mathrm{~g} / \mathrm{d}(50.7 \%$ of total $\mathrm{N})$; reabsorption of endogenous $\mathrm{N}$ amounted to $71 \%$. These findings correspond with those of the presented study. Only for secretion of endogenous $\mathrm{N}$ in the second intestinal section (small intestine) our value $(4.4 \mathrm{~g} \mathrm{~N} / \mathrm{d})$ is lower and probably underestimated in relation to the findings of Van Bruchem et al.(1997). It is not excluded that the digesta exchange between animals had some influence on $\mathrm{N}$ secretion along the small intestine. However, the accuracy of the estimations decreases progressively towards the end of the digestive passage and these preliminary values should be considered with some caution and verified in further experiments.

It is important for the proper course of this type of experiment with animals to ensure a similar course of digestion processes for all 3 animals during the whole trial. For this it is necessary not only to reach an identical feed and $\mathrm{N}$ intake for all 3 animals but also an exchange of digesta approximately synchronized in time and amount. These conditions were not totally fulfilled in our experiment as the $\mathrm{N}$ intake of animal No. 2 from the beginning of the exchange period was considerably lower than for both other animals, though they were similar during the labelling period. Therefore, a correction factor for percentage compensation was needed accepting assumption that the ratio of endogenous $\mathrm{N}$ :exogenous $\mathrm{N}$ will be constant for all three animals and will not be influenced by the food intake.

Absorption of total $\mathrm{N}$ and endogenous $\mathrm{N}$ in different sections of the digestive tract is usually calculated by the difference between the $\mathrm{N}$ input and the $\mathrm{N}$ output of the segment being examined. The quantity of truly absorbed $\mathrm{N}$ is mostly underestimated because the amount of endogenous $\mathrm{N}$ secreted into the lumen of this particular section and being absorbed before reaching its end is difficult to evaluate (Żebrowska et al., 1992). Such difficulty was avoided to a high degree in the presented experiment by estimating the true appearance and disappearance rate of ${ }^{15} \mathrm{~N}$ labelled endogenous $\mathrm{N}$ of digesta passing through the particular intestinal section. Therefore, the secretion and absorption rates found in the experiment, espe- 
cially those for reabsorption of endogenous $\mathrm{N}$, are somewhat higher than those in earlier studies.

Another problem to be resolved is the assumption of nearly constant composition or even of approximately the same ${ }^{15} \mathrm{~N}$ level for all endogenous secretions along the intestinal tract (saliva, bile, pancreatic juice, ruminal and intestinal secretions). This is a simplification which is necessary for calculation of the endogenous part of $\mathrm{N}$ in the different sections of the digestive tract. This problem is relevant also for all the other methods for estimating endogenous $\mathrm{N}$ metabolism applying isotopic dilution methods. The possible error or deviation caused by this simplified assumption will be taken into consideration and quantified in further studies.

In summary, it may be concluded that the dynamics of metabolic processes during $\mathrm{N}$ digestion in ruminants are often underestimated. The combination of the ${ }^{15} \mathrm{~N}$ tracer technique and digesta exchange between labelled and unlabelled animals seems to be a suitable method for this purpose.

\section{REFERENCES}

Beever D.E., Harrison D.G., Thomson D.J., Cammell S.B., Osbourn D.F., 1974. A method for estimation of dietary and microbial protein in duodenal digesta of ruminants. Brit. J. Nutr. 32, 99-112

Bergner U., Bergner H., Simon O.,1984. Untersuchungen zu endogenen N-Umsatzprozessen an ${ }^{15} \mathrm{~N}$-markierten Schweinen. 2.Mitt. Fäkale Exkretion von Aminosäuren und ${ }^{15} \mathrm{~N}$-markierten Aminosäuren bei unterschicdlichem Rohfasergehalt der Diäten. Arch. Anim. Nutr. 34, 505-517

Bergner U., Bergner H., 1982. Prüfung der Proteinverdaulichkeit in einzeln Darmabschnitten unter in vivo Bedingungen an Versuchsratten nach der Isotopenverdünnungsmethode. Arch. Anim. Nutr. $32,841-852$

De Lange C.F.M., Souffrant W.B., Sauer W.C., 1990. Real ileal protein and amino acid digestibilities in feedstuffs for growing pigs as determined with ${ }^{15} \mathrm{~N}$ isotope dilution technique. J. Anim. Sci. 78, 409-418

Hernandez M., Simon O., Bergner H., 1981. Eine neue Methode zur Prüfung der Qualität von Nahrungsproteinen für den Erhaltungsstoffwechsel. 3. Mitt. Methodische Untersuchungen an ${ }^{15} \mathrm{~N}$-markierten ausgewachsenen Ratten. Arch. Anim. Nutr. 31, 651- 660

Huisman J., Heinz T., Van der Poel A.F.D., Van Lecuwen P., Souffrant W.B., Verstegen M.W.A., 1992. True digestibility and amounts of endogenous protein measured with the ${ }^{15} \mathrm{~N}$ technique in piglets fed on peas (Pisum sativum) and common beans (Phaseolus vulgaris). Brit. J. Nutr. 68, 101-110

Huisman J., Verstegen M.W.A., Van Leeuwen P., Tamminga S., 1993. Reduction of N pollution by decrease of excretion of endogenous $\mathrm{N}$ in pigs. In: M.W.A. Verstegen, L.A. den Hartog, G.J.M. van Kempen, J.H.M. Metz (Editors). Nitrogen Flow in Pig Production and Environmental Consequences. Wageningen (The Netherlands), Pudoc Scientific Publishers, pp. 55-61

Ivan M., Lamand, M., Kelleher C.A. Mason J., 1981. Exchange of digesta via duodenal cannula in sheep. A technique useful for absorption studies with labelled compounds. Ann. Rech. Vet. 12, 379-383 
Kowalczyk J., Havassy I., Otwinowska A., Košta K., 1975. Passage of intravenously administered ${ }^{15} \mathrm{~N}$ urea into the digestive tract and its excretion in sheep. Acta physiol. pol. 26, 299-306

Kowalczyk J., Skiba B., Buczkowski Z., Kowalik B., 1996. A device for quantitative urine collection from male sheep in balance trials. J. Anim. Feed Sci. 5, 297-301

Krawielitzki K., Völker T., Buraczewska L., Żebrowska T., Wünsche J., Hennig U., Bock H.-D., 1979. Untersuchungen über die Proteinverdaulichkeit und Aminosäureresorption in verschiedenen Abschnitten des Verdauungstraktes beim Schwcin. 6. Mitt.: Ergebnisse der Applikation von ${ }^{15} \mathrm{~N}$ Lysin. Arch. Tierernähr. 29, 771-780

Krawielitzki K, Żebrowska T., Kreienbring F., Schadereit R., Kowalczyk J., 1996. Absorption and secretion of endogenous and exogenous $\mathrm{N}$ along the digestive tract and kinetic parameters of protein metabolism in growing pigs. 1. Estimation by digesta exchange between labelled and unlabelled pigs. J. Anim. Physiol. Anim. Nutr. 76, 46-56

Krawielitzki K., Żebrowska T., Schadereit R., Kowalczyk J., Hennig U., Wünsche J., Herrmann U., 1990. Determining of nitrogen absorption and nitrogen secretion in different sections of pig's intestine by digesta exchange between ${ }^{15} \mathrm{~N}$ labelled and unlabelled animals. Arch. Anim. Nutr. 40, 25-37

Krawielitzki K., Żebrowska T., Schadereit R., Kowalczyk J., Kreienbring F., 1993. Estimation of N absorption and secretion by digesta exchange between labelled and unlabelled pigs. Isotopenpraxis Environ. Health Stud. 29, 157-162

Kuhla S., Schmidt L., 1996. Schätzung der umsetzbaren Energie von Grundfutter für Wiederkäuer mittels einer Cellulase-Methode. Proc. Soc. Nutr. Physiol. 5, 115

Kuhla S., Weißbach F., 1996. Schätzung der umsetzbaren Energie von Mischfutter für Wiederkäuer mittels einer Cellulase-Methode. Proc. Soc. Nutr. Physiol. 5, 116

Low A.G., Żebrowska T., 1989. Digestion in pigs. In : H.-D. Bock, B.O. Eggum, A.G. Low, O. Simon, T. Żebrowska (Editors). Protein Metabolism in Farm Animals - Evaluation, Digestion, Absorption and Metabolism. Oxford University Press, pp. 53-121

Naumann K., Bassler R., 1993. Methodenbuch, Band III, 3. Erg., Verlag J. Neumann; Neudamm, Melsungen

Oosting S.J., Van Bruchem J., Chen X.B., 1995. Intake, digestion and small intestinal protein availability in sheep in relation to ammoniation of wheat straw with and without protein supplementation. Brit. J. Nutr. 75, 347-368

Pahle T., Köhler R., Gebhardt G., Souffrant W.B., Rühe C., 1981. Zum N-Stoffwechsel und seiner Modellierung nach Versuchen mit ${ }^{15} \mathrm{~N}$-markiertem Weizen an Ratten. Arch. Anim. Nutr. 31, 127-140

Schubert R., 1995. Untersuchungen zum N- und Aminosäuren-Stoffwechsel laktierender Stuten am

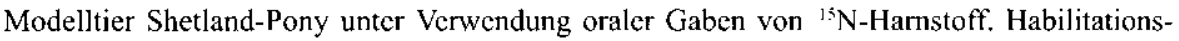
schrift an der Agrarwissenschaftlichen Fakultät der Universität Jena (Germany)

Souffrant W.B., 1991. Endogenous nitrogen losses during digestion in pigs. In: M.W.A. Verstegen, J. Huisman, I.A.den Hartog (Editors). Digestive Physiology in Pigs, Wageningen (The Netherlands), Pudoc Scientific Publishers, pp. 147-166

Van Bruchem J., Bongers L.J.G., Lammers-Wienhoven T.S.C.W., Bangma G.A., Van Adrichem P.W.M., 1989. Apparent and true digestibility of proteins in losses of endogenous protein from small intestine in sheep as related to dry matter intake and digestibility. Livest. Prod. Sci. 23, 317-327

Van Bruchem J., Voigt J., Lammers-Wienhoven T.S.C.W., Schönhusen U., Ketelaars J.J.M.H., Tamminga S., 1997. Secretion and reabsorption of endogenous protein along the small intestine of sheep: Estimates derived from ${ }^{15} \mathrm{~N}$ dilution of plasma-non-protein N. Brit J. Nutr. 77, 273-286

Voigt J., Krawielitzki R., Piatkowski B., 1980. Untersuchungen zur Wirkung von Phosphorsäurephenylesterdiamid als Inhibitor der Pansenurease bei der Milchkuh. 2. Mitt.: Der Umsatz von ${ }^{15} \mathrm{~N}$-Harnstoff. Arch. Anim. Nutr. 30, 825- 834 
Voigt J., Van Bruchem J., Krawielitzki K., Lammers-Wienhoven T.S.C.W., Schönhusen U., Tamminga S., Hagemeister H., 1996. Untersuchungen zum Recycling von Stickstoff beim Schaf. Proceedings of the International Meeting "Problems of Protein Nutrition of Animals", Nitra (Slovakia), pp. $15-21$

Voigt J., Van Bruchem J., Lammers-Wienhoven T.S.C.W., Ketelaars J.J.M.H., Tamminga S.,1994. Flow of endogenous protein along the small intestine of sheep - Effect of cell walls. Proc. Soc. Nutr. Physiol. 3, 104

Żebrowska T., Kowalczyk J., 1991. Nitrogen secretion into isolated loops of the small intestine in conscious sheep. J. Anim. Physiol. Anim. Nutr. 65, 133-139

Żebrowska T., Kowalczyk J., Krawielitzki K., Hennig U., Schadereit U., 1992. Studies on absorption and secretion of ${ }^{15} \mathrm{~N}$ endogenous nitrogen along the digestive tract of pigs. J. Anim. Feed Sci. 1, $151-163$

\section{STRESZCZENIE}

\section{Wydzielanie i wchłanianie azotu w różnych odcinkach przewodu pokarmowego owiec, ozna- czone metodą wymiany treści między zwierzętami znakowanymi ${ }^{15} \mathrm{~N}$ i nie znakowanymi}

Badania prowadzono na trzech tryczkach o masie ciała około $25 \mathrm{~kg}$ z przetokami do żwacza i przetokami mostkowymi w początkowej części dwunastnicy oraz końcowej jelita biodrowego. Owca No.1 otrzymywała dożwaczowo w infuzji ciągłej ${ }^{15} \mathrm{~N}$ mocznik $\left(1 \mathrm{~g} / \mathrm{d} 95 \%\right.$ nadmiaru $\left.{ }^{15} \mathrm{~N}\right)$, natomiast owce No.2 i 3 takie same ilości mocznika nie znakowanego. Wszystkim zwierzętom podawano dziennie dawki paszowe zawierające $800 \mathrm{~g} \mathrm{SM}$, złożone z siana łąkowego i paszy treściwej w proporcji 40:60. Dawki zawierały $15,4 \%$ białka ogólnego i 15,3\% włókna surowego. Paszę podawano w 6 jednakowych porcjach co 4 godziny. Po osiągnięciu stanu równowagi w poziomie ${ }^{15} \mathrm{~N}$ u owcy No.1 oznaczano przepływ $\mathrm{N}$ ogólnego i ${ }^{15} \mathrm{~N}$ przez dwunastnicę i jelito biodrowe oraz ich wydalanie w moczu i kale. W siódmym i ósmym dniu doświadczenia wymieniano treść wypływającą z dwunastnicy i jelita biodrowego między znaczonym izotopem zwierzęciem No.1 a nie znaczonymi No. 2 i 3, zgodnie z przyjętym schematem. Przepływającą w ciągu 48 godz. treść ważono i pobierano $3 \%$ próby do analiz na zawartość $\mathrm{N} \mathrm{i}{ }^{15} \mathrm{~N}$. Zawartość $\mathrm{N} \mathrm{i}{ }^{15} \mathrm{~N}$ oznaczano również w kale, moczu i odbiałczonej plazmie krwi. Na podstawie uzyskanych wyników obliczono przepływ i ilość wchłanianego $\mathrm{N}$ egzogennego oraz wydzielanego i ponownie wchłanianego azotu endogennego w trzech częściach przewodu pokarmowego, a mianowicie na odcinku do początkowej części dwunastnicy, w jelicie cienkim i grubym.

Ilość przepływającego $\mathrm{N}$ ogólnego, egzogennego i endogennego zmniejszała się od dwunastnicy poprzez jelito cienkie do kału, ale udział $\mathrm{N}$ endogennego zwiększał się w tych odcinkach od 36 do $54 \%$. Wydzielanie $\mathrm{N}$ było największe w pierwszej części przewodu pokarmowego $(9,9 \mathrm{~g} / \mathrm{d})$, co stanowiło $60 \% \mathrm{~N}$ wydzielonego do całego przewodu pokarmowego, natomiast wchłanianie było najwyższe w drugim odcinku $(14,1 \mathrm{~g} \mathrm{~N} / \mathrm{d}=46 \% \mathrm{~N}$ wchłoniętego). $\mathrm{N}$ pochodzenia endogennego stanowił 54\% azotu zawartego w kale. Straty N endogennego w kale wynosiły $2 \mathrm{~g} / \mathrm{d}$, co stanowiło $12 \%$ ogólnej ilości azotu endogennego $(16,5 \mathrm{~g})$ wydzielonego do światła jelita. Całkowita reabsorpcja azotu endogennego wynosiła $88 \%$. Uzyskane w doświadczeniu wyniki wskazują na wysoką dynamikę przemian azotu u przeżuwaczy. 